\title{
The Theoretical Foundations of Management in Terms of the Implementation of the Process of Globalization and Sustainable Development in the Real Sphere
}

\section{Teoretyczne podstawy zarządzania $w$ aspekcie implementacji do sfery realnej procesu globalizacji i zrównoważonego rozwoju}

\author{
Franciszek Piontek
}

\author{
WSB University in Dąbrowa Górnicza, Poland \\ E-mail:f_piontek@wp.pl
}

\begin{abstract}
The implementation of a process of globalization and sustainable development based on management requires integration. It can be ensured by the rules of universal operation:

- on the side of the process of globalization, it is necessary to recognize economic growth as a component of development and recognize the primacy of development over growth, verifying the functions of the rules of universal operation, and limiting the paradigms of deregulation (YES = NO=CAN BE);

- the primacy of federal integration over structural one; the application of management in accordance with the nature of the sphere covered by management and open to the exemplification of the functions and rules of universal operation;

- on the side of sustainable development: the use of the process of globalization solutions in the field of technological progress, institutional procedures, which contribute to improving the quality, effectiveness and efficiency (quality of life).

In addition to necessary conditions, decision-making will be necessary, which is a sufficient condition.
\end{abstract}

Key words: management, globalization process, sustainable development, integrated implementation, civilization code, deregulation paradigm

\section{Streszczenie}

Implementacja procesu globalizacji i zrównoważonego rozwoju w oparciu o zarządzanie wymaga zintegrowania. Mogą je zapewnić reguły powszechnego postępowania:

- Po stronie procesu globalizacji wymaga się: uznania wzrostu gospodarczego, jako składowej rozwoju i nadrzędności rozwoju nad wzrostem, weryfikujących funkcji reguł powszechnego postepowania, ograniczanie paradygmatów deregulacji $($ TAK $=$ NIE $=$ BYĆ MOŻE);

- $\quad$ nadrzędności integracji federacyjnej nad strukturalną; stosowania zarządzania zgodnie z naturą sfery objętej zarządzaniem i otwartego na egzemplifikację funkcji i reguł powszechnego postępowania;

- po stronie zrównoważonego rozwoju: wykorzystanie rozwiązań procesu globalizacji w zakresie postępu technologicznego, procedur instytucjonalnych, które przyczyniają się do poprawy jakości, efektywności, sprawności funkcjonowania ( jakości życia).

Obok warunków koniecznych potrzebna jest wola decyzyjna - warunek dostateczny.

Słowa kluczowe: zarządzanie, proces globalizacji, zrównoważony rozwój, zintegrowana implementacja, kod cywilizacyjny, paradygmat deregulacji 


\section{Introduction}

The following reasons justify addressing the subject of this article:

- Changes in the management by type: an increased object scope and tools which enable its wide application;

- Changes in the real sphere by type resulting from the implementation of the (alternative) concepts of development.

The objectives of the article are as follows:

- The assessment of the correctness of management application for the implementation of the development concept in the real sphere;

- Criteria for the correct application of the category of management. The article does not aim to broadly analyze management concepts and tools.

A research hypothesis:

1. The implementation of the alternative concepts of development excludes the separate treatment of management concepts and types;

2. The integration of the alternative concepts and types of management is ensured by the principles of universal operation in its criterion function.

The aim and hypothesis determine the following structure of the article:

1. The alternative concepts of development in terms of the structural order and criterion-related requirements for management;

2. Management in relation to the separation and integration of the alternative concepts of development;

3. The assumptions and effects of the separation of the concepts of development and management in their implementation in the real sphere;

4. Criteria for the integral implementation of the alternative concepts of management in the real sphere.

The article is synthetic.

1. The alternative concepts of development in terms of the structural order and criterionrelated requirements for management

A starting point for the discussion is to distinguish two alternative subsets of the concept of development:

- concepts based on unsustainability processes;

- $\quad$ concepts based on sustainability processes.

(Piontek, Piontek 2016, p. 37 et seq.; Piontek, Piontek 2017, p. 35 et seq., Piontek 2002): a process of globalization - a component of the first subset,

- $\quad$ sustainable development - in the second subset. In the literature, both concepts are explained by a large number of definitions (Piontek 2016, p. 48, Piontek 2002, p. 16-26).
The definition which shows the essence of the process of globalization is: the river of free capital (loans; Martin Schumann, 1999, p. 38-41). This definition is specified by S. Solomon: a stream of stateless (private F.P.) money (Solomon 2000, p. 16). Connectors are tailored programs: they shape the economic structure of the borrower and they are subject to financial engineering. Their compliance with the constitution of a given country is not examined (Piontek, 2019).

The author's definition of sustainable development is as follows: it is the process of transformation, changes, transition to states or more perfect forms, subordinated to human capital (which serves man) and satisfying the criteria articulated by the rules of universal operation (norms of the Constitution of the World; Piontek, Piontek, 2019). The concept of sustainable development is focused on shaping the structural order, reducing socio-economic inequalities and improving relationality, which is a condition for ensuring globality on an international scale (Piontek 2019).

Both concepts:

- are comparable in terms of their material scope (material object). They cover not only the economic sphere, but also, to a large extent, the sphere of civilization;

- $\quad$ are diversified by their attitude to the rules of universal operation (the norms of the Constitution of the World; Piontek, Piontek 2019) and in particular, to the civilization code.

The comparison of both concepts requires a reference to the foundation of the functioning of the world. It is the principle of diversity (dualism, pluralism), which accepts the substance diversity of beings. It is confirmed by the Bible (Gen. 11.1-9), Koran $(5 / 48)$, research in the world of nature, and as regards the spiritual sphere of man (Nobel, 1963), it was confirmed empirically by J. Eccles (Eccles 1994). This principle covers matter and spirit and the existing diversity in the set of matter and spirit.

According to this principle, the concept of sustainable development covers three types of capital: economic, human and natural, with the primacy of human capital. It is a natural concept, inscribed in the nature of the World and defining its functioning, in accordance with the nature and the principle of $d i$ versity.

The principle of homogeneity (materialistic and spiritualistic monism) is a denial of the principle of $d i$ versity (antithesis). This principle is not inscribed in the nature of the functioning of entities. Both materialistic and spiritualistic monism is purely institutional. The concept of development based on this principle, which is a process of globalization, is also exclusively an institutional solution. This fact definitely determines the separation of sustainable development and the process of globalization unambiguously. 
The process of globalization is focused on economic capital (monism) to a large extent, and the remaining types of capital are production factors. The institutional nature of the process of globalization makes it possible to deepen the separation of this concept and sustainable development by using other institutional solutions:

- $\quad$ negating the rules of universal operation and replacing them with paradigms formulated institutionally;

- $\quad$ negating the civilization code (point 3);

- changing the nature of science and education (Piontek, Piontek 2019, Piontek 2019);

- $\quad$ negating alternative concepts;

- using types of management in a highly arbitrary manner (point 3);

- $\quad$ seeking integration based on the principle of end-of-pipe effects (an environmental protection concept). UN Conferences: Monterrey, Johannesburg: priorities - sustainable development and management tools from the process of globalization (Piontek, Piontek 2017, section 5.3).

The article attempts to determine the conditions for the integration of these separate concepts at their bases and with the use of management types (concepts and tools).

\section{Management in relation to the separation and integration of the alternative concepts of development}

The purpose of point 2 is to show the theoretical foundations which diversify the category of management in the implementation of the alternative concepts of development in the real sphere.

The generally accepted classification distinguishes several subsets (concepts and tools) of management and indicates the multi-faceted application of this category:

- $\quad$ in terms of the functions performed:

- management understood broadly (sensu largo): management, administration and public management include the functions of planning, organizing, motivating and controlling;

- systemic management - focused on processes occurring in systems and in the relationship to the environment; to ensure the efficient functioning of systems;

- $\quad$ as a set of procedures:

- can be a component of institutional solutions (building an organization and defining procedures for its functioning - statutory law);

- can be classified as technology (technologies are procedures; Ritzer 1999, pp. 174178);
- as a concept for the strategy of system and company functioning:

- reengineering - the radical redesign of processes in a company for dramatic, breakthrough improvement of results (staff, quality, service and speed of action (Zimniewicz 1999, p. 16);

- benchmarking - equalling the highest achievers in a given field, learning from competitors (Zimniewicz, p. 36);

- outsourcing - a new look at the functioning of supply; it also includes service activities (including information processing and parts production, outsourced to specialist companies (Zimniewicz, p. 48).

These concepts and procedures do not exhaust this subset (Zimniewicz, 1999); other terms, but belonging to the set of management, e.g. marketing, are necessary, but there are many types of marketing. Extreme marketing can be the management of consciousness, the choices of customers, stakeholder, and politicians.

For example, the highlighted types (concept and tools) of management:

- $\quad$ were built on the basis of broadly understood economic capital and the paradigm of a free market;

- $\quad$ include other types of capital, thus specifying how they operate in a free market;

- $\quad$ targeted, primarily focused on increasing economic capital by maximizing operational efficiency.

This range of activities is desirable, but within optimal ranges.

- $\quad$ as institutional solutions, they can use technologies to a large extent;

- $\quad$ in the process of implementation in the real sphere, they can ensure the supremacy of the process of globalization over sustainable development. In this case, the concept is disconnected rather than integrated.

3. The assumptions and effects of the separation of the concepts of development and management in their implementation in the real sphere

The objectives of this point are as follows:

- to indicate the theoretical foundations which determine the separation of management in its implementation to the real sphere,

- to present effects conditioned by this separation.

The separation of the types (concepts and tools) of management (point 2) is conditioned by the separation of sustainable development and the process of globalization (point 1):

- by their different nature (a natural concept versus an institutionally formulated concept, point 1); 
- $\quad$ an attitude to the rules of universal operation and in particular, to the civilization code, which is the principle of contradiction.

The separation of sustainable development and the process of globalization determines the separation of management types (separate concepts need different tools). In the language of logic, the civilization code is the principle of contradiction:

$\mathrm{YES} \neq \mathrm{NO}$

It determines the foundations of civilization: truth $\neq$ false; good $\neq$ evil; and beauty subordinated to human tastes should serve truth and goodness. The civilization code directs the types (concepts and methods) of management towards including the foundations of civilization in building the concept of sustainable development and in implementing it into the real sphere.

The Group of Lisbon mentions deregulation as one of the principles (paradigm; G.L. 1996, pp. 65-67) of the process of globalization. This paradigm consists of breaking the civilization code. In the language of logic, it is written as follows:

$$
\mathrm{YES}=\mathrm{NO}=\mathrm{CAN} \mathrm{BE}
$$

This paradigm is the basis of the institutionally built concept of the process of globalization, and at the same time it determines other institutional solutions:

- $\quad$ separation of the process of globalization and sustainable development;

- $\quad$ separation of management types (concepts and tools).

The effects of separation in the set of management:

- constructing such types of management that are not open to the rules of universal operation and do not ensure a wide range of sustainability processes (including relationality and the structural order);

- management orientation - to a large extent, an impact on economic growth (de facto a component of development) and on the primacy of growth over development, and thus the primacy of the process of globalization over sustainable development;

- the education of human capital may be limited to improving contractors' efficiency, in accordance with the needs for management (Piontek, Piontek, 2019);

- business management concepts and tools can be used for public and strategic management (point 3);

- the superiority of process management over functional management is emphasized because the structure of the organization (micro) is determined by processes, not functions (Hammer, Champy 1996, p. 112). And what determines the structure of the strategy?

- free market-oriented management (short-term, competition based on the paradigm of deregulation) ignores the strategic sphere. It can be used exogenously;
- building integration and relationality - it is not verified in terms of criteria for globality on a national and international scales (Piontek 2019);

- $\quad$ the need to integrate the process of globalization and sustainable development is recognized internationally. The model is the end-of-pipe effect (an environmental protection term - see point 1).

Thus, the types of management (concepts and tools) built on the basis of the paradigm of deregulation limit the possibilities of integration of the process of globalization and sustainable development in their implementation in the real sphere.

\section{Criteria for the integrated implementation of the alternative concepts of development in the real sphere}

The purpose of the point is to indicate the criteria for integrating separate concepts in the real sphere:

- on the side of the process of globalization:

- recognizing economic growth as a component of the category of development and recognizing the primacy of development over growth;

- $\quad$ recognizing the verifying functions of the rules of universal operation, and in particular, taking them into account in institutional solutions;

- $\quad$ limiting the paradigm of deregulation and not replacing the rules of universal operation with institutionally formulated paradigms (Kuhn, 1962);

- $\quad$ using such types (concepts and tools) of management that can be verified by the rules of universal operation and constructing them in accordance with the nature of the sphere covered by management;

- $\quad$ strengthening the need to build the structural order and the primacy of federal integration over structural one (it concerns the integration of states);

- $\quad$ on the side of sustainable development:

- using such solutions of the process of globalization that can be verified by the rules of universal operation in the field of technological progress, institutional procedures, which contribute to improving the quality, efficiency and effectiveness of functioning (improving the quality of life; Sztumski 2019, pp. 25-32);

- $\quad$ on the management side, the following is necessary:

- integration between business management and public management;

- integration between free market-oriented management and strategic management;

- $\quad$ limiting the unified and standardized lan- 
guage in system and process approaches, which undermines the principle of diversity of beings and implements the principle of homogeneity (monism; the postulate does not apply to standardization in production).

A certain degree of separation of management types (cf. point 2) is a natural phenomenon, conditioned, among others, by the nature of the management sphere. Criteria formulated based on the rules of universal operation and institutional solutions based thereon can ensure the proper functioning of management types in the process of implementing alternative concepts in the real sphere.

\section{Conclusion}

The article presents the conditions necessary for the integrated implementation of the process of globalization, sustainable development and management in the real sphere. It should be emphasized that the decision-making will which determines effectiveness in this respect is a sufficient condition. This will cannot consist of broadly understood consent shaped by the paradigm of deregulation. As a rule, such consent circumvents norms in state constitutions. In turn, the will to build a new civilization cannot be an unfalsifiable priority.

\section{References}

1. ECCLES J.C., 1994, How the Self Controls Its Brain, Springer-Verlag, Berlin, New York.

2. GRUPA LIZBOŃSKA GL, 1996, Granice konkurencji, Poltext, Warsaw.

3. HAMMER M., CHAMPY J., 1996, Reengineering w przedsiębiorstwie, Neumann Man. Inst., Warsaw.
4. KUHN T.S., 1962, The Structure of Scientific Revolutions, University of Chicago Press, Chicago.

5. MARTIN H.P., SCHUMANN H., 1999, Proces globalizacji. Atak na demokracje i dobrobyt, Wydawnictwo Dolnośląskie, Wrocław.

6. PIONTEK B., 2002, Alternatywne koncepcje urzeczywistniania powszechności $\mathrm{w}$ procesie rozwoju, in: Kapitał ludzki w procesie globalizacji a w zrównoważonym rozwoju, ed. Piontek F., Bytom.

7. PIONTEK B., 2002, Koncepcja rozwoju zrównoważonego i trwałego Polski, Wydawnictwo Naukowe PWN, Warsaw.

8. PIONTEK B., PIONTEK F., 2017, Development from Theory to Practice, Shaker Verlag, Aachen.

9. PIONTEK F., 2019, Teoretyczne podstawy integracji i globalności w aspekcie zarządzania rozwojem zrównoważonym, in: Prace Komisji Geografii Przemystu Polskiego Towarzystwa Geograficznego, eds. Zioło. Z., Rachwał T., Cracow.

10. PIONTEK F., PIONTEK B., 2016, Teoria rozwoju, PWE, Warsaw.

11. PIONTEK F., PIONTEK B., 2019, Theoretical Foundations of Human Capital Education in Economic Growth and Development Management, in: Problemy Ekorozwoju/ Problems of Sustainable Development, 14(1), p. 167-173.

12. RITZER G., 1993, The McDonaldization of society: an investigation into the changing character of contemporary social life, Sage Publications, Thousand Oaks, California, USA.

13. SALOMON S., 1995, The Confidence Game: How Unelected Central Bankers Are Governing the Changed Global Economy, Simon \& Schuster, New York.

14. ZIMNIEWICZ K., 1999, Współczesne koncepcje zarządzania, PWE, Warsaw.

15. SZTUMSKI W., 2019, For Further Social Development, Peaceful, Safe and Useful for People, in: Problemy Ekorozwoju/ Problems of Sustainable Development, 14(2), p. 25-32. 
